Vantage: Journal of Thematic Analysis

ISSN: 2582-7391

A Multidisciplinary Publication of Centre for Research, Maitreyi College, University of Delhi

April 2021, Volume 2, Issue 1

Review Article

\title{
COVID-19 Vaccine: The Fight Against SARS-CoV-2 Infection
}

\author{
Saima Syeda and Anju Shrivastava* \\ Department of Zoology, University of Delhi, Delhi-110007, India. \\ *Correspondence: anjushrivastava.du@gmail.com
}

\begin{abstract}
Severe acute respiratory syndrome coronavirus 2 (SARS-CoV-2) caused the pandemic in the year 2020, leading to disruption of the healthcare system with a great impact on socio-economy worldwide. Owing to this, an accelerated development of safe and efficient vaccines is required to fight against this virus. In this line, various vaccine development platforms have been exploited globally in order to manage the exponentially increasing rate of infection and mortality. Some vaccines in clinical phase trials have entered into emergency use authorization by few countries while others are in a preclinical stage. The present review summarizes the various platforms of vaccine development and also gives an insight into the vaccination programme initiated in India.
\end{abstract}

KEY WORDS: SARS-CoV-2, vaccine platforms, COVID-19 vaccine

\section{INTRODUCTION}

The outbreak of SARS-CoV-2, a new viral pathogen of humans, emerged from the Wuhan city of China in November, 2019. This contagious virus caused respiratory illness leading to a high rate of mortality (Shin et al., 2020). The virus was found to belong to the betacoronavirus class and thus the disease is known as coronavirus infectious disease-19 (COVID-19). Thereafter, the disease spread to many other countries at an alarming rate and on $11^{\text {th }}$ March, 2020, World Health Organization (WHO) identified COVID-19 as a pandemic (Shin et al., 2020). As of $21^{\text {st }}$ March 2021, there have been $122,524,424$ confirmed cases of COVID-19 globally which included 2,703,620 deaths (“WHO coronavirus disease (COVID-19) dashboard”, 2021).

Vantage: Journal of Thematic Analysis, 2021; 2(1): 42-66 
In order to control the exponentially increasing rate of infection of this highly contagious disease, most of the countries implemented various strategies such as use of masks, social distancing, frequent hand washing, disinfection of surfaces ("How COVID-19 spreads", 2020). These strategies have prevented people from getting the infection; however, these people would be susceptible to additional waves of infection. Also, senior citizens and those with weak immunity are at high risk of infection. So, for protection of the global community from the SARS-CoV-2 infection, there was a need to develop immunity among all the citizens which could be accomplished by vaccination programmes. In view of this, researchers focused on development of safe and effective vaccines by employing various parallel vaccine strategies, initiated with collaboration of biotechnology, pharmaceutical companies, government and academia, each aiding the vaccination programme through their individual strengths. This review gives insight into the various strategies used in vaccine development that led to the emergence of multiple vaccines globally. Also, we give the status of vaccines in the clinical phase, with particular focus on vaccination programmes in India.

\section{COVID-19 VACCINE: CONCEPT OF DEVELOPMENT}

The rapid spread of SARS-CoV-2 infection prompted researchers all around the world to develop a safe and efficient COVID-19 vaccine. To explore the various platforms of vaccine development, understanding the protective immune response is imperative. Exponentially emerging reports suggested that the immune response against SARSCoV-2 is similar to the response against SARS-CoV outbreak that occurred during 2002-03 in China or Middle East Respiratory Syndrome Coronavirus (MERS-CoV) outbreak that occurred in 2012 in Saudi Arabia (Prompetchara et al., 2020). SARS$\mathrm{CoV}-2$ has been revealed to suppress innate immune system activation as well as type I and type II interferon response (Blanco-Melo et al., 2020; Remy et al., 2020). Therefore, these parameters could be considered for development of the COVID-19 vaccine. Moreover, during vaccine development, there are a few considerations, such as its safety and efficacy, which need to be identified as well as quantified. There have been two known syndromes associated with post vaccine administration. First is

Vantage: Journal of Thematic Analysis, 2021; 2(1): 42-66 
antibody-dependent enhancement (ADE) and second is vaccine-associated enhanced respiratory disease (VAERD). In ADE, the binding of virus-antibody complex to Fc(tail region of antibody)-receptor shows high efficiency. This has been shown to happen when vaccine-induced antibodies fail to neutralize the virus effectively, either due to low antibody titre or due to wrong specificity. This disease has been observed earlier in feline infectious peritonitis virus (FIPV), a corona virus that targets macrophages for infection (Dowd \& Pierson, 2011). In addition, it has also been observed in SARS-CoV-1 infection in in-vitro condition wherein human B cell lymphoma cell line was used; however, no infectious virus was produced. Likewise, no in-vivo report suggested such ADE-associated pathophysiology (Jaume et al., 2011). In contrast, VAERD was observed in young children vaccinated for respiratory syncytial virus (RSV) and measles (Polack, 2007). This disease has been known to be caused by two phenomena- high ratio of binding antibody to neutralizing antibody and allergic inflammation (Graham, 1996; Polack et al., 2002). In the first phenomenon, a large amount of antibody binds to high viral load but is unable to neutralize them. This results in immune complex deposition and complement activation (Polack et al., 2002). The second phenomenon of allergic inflammation is associated with production of specific cytokines such as interleukin $-4,-5$ and -13 that lead to eosinophil recruitment, attenuated cytotoxic $\mathrm{T}$ cell activity and hyper responsiveness (Graham, 1996). These phenomena have been known to potentiate airway dysfunction and delay the viral clearance. The VAERD can be avoided by skewing $\mathrm{T}_{\mathrm{H}}$ response towards $\mathrm{T}_{\mathrm{H}} 1$ type. Therefore, during vaccine development against SARS-CoV-2, these parameters are being considered to demonstrate the safety and efficacy of a vaccine.

\section{VACCINE PLATFORMS}

With the SARS-CoV-2 outbreak, there was an urgent need of an efficient and safe vaccine globally. The researchers all around the world focused on vaccine development which also compressed the timeline from 10-15 years to just 1-2 years. These vaccines are based on various platforms which can be categorized as classical and next generation (Figure 1).

Vantage: Journal of Thematic Analysis, 2021; 2(1): 42-66 


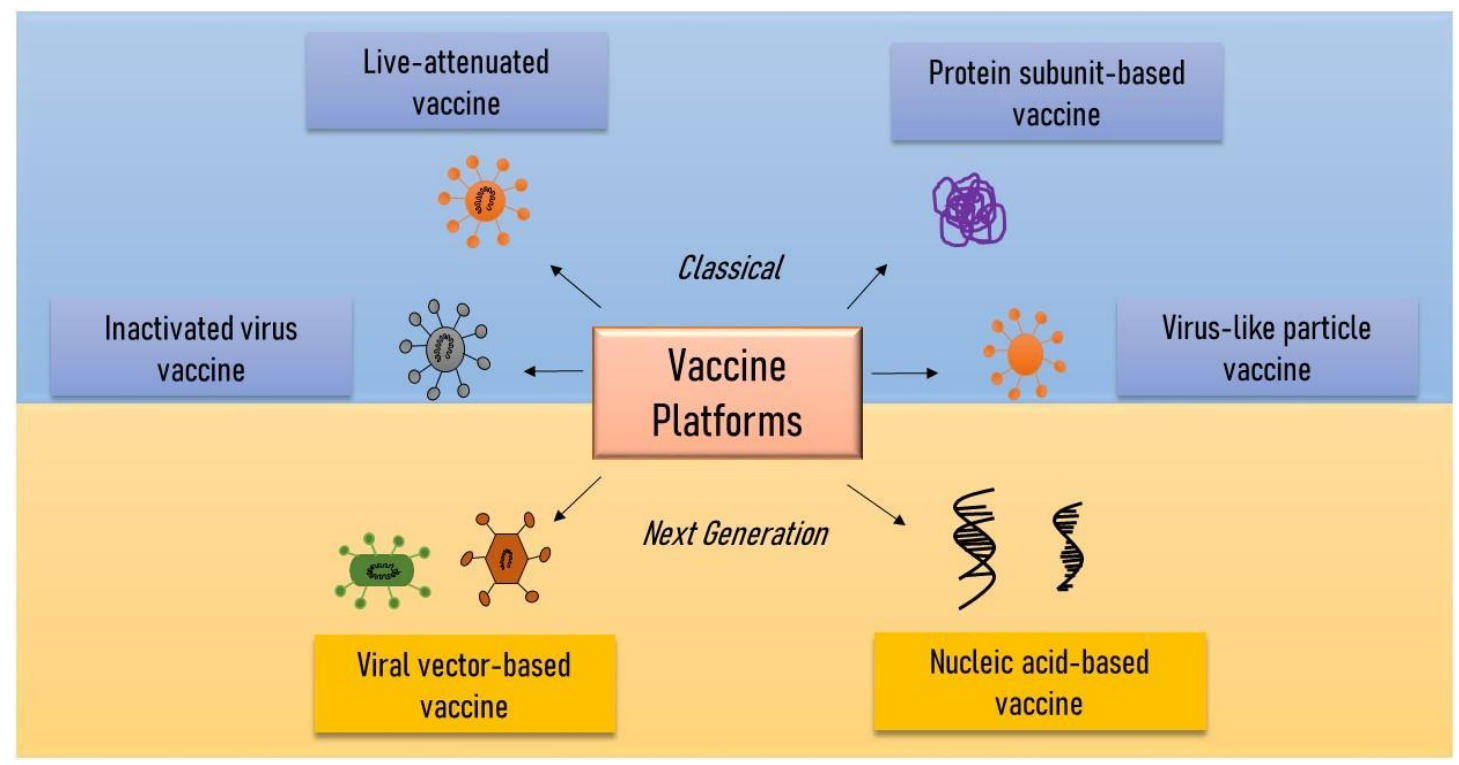

Figure 1: The vaccine platforms used for development of various vaccine candidates against SARS-CoV-2 infection

In classical vaccine platforms, the strategies include the use of virus (either live attenuated or inactivated) or its protein subunit. On the other hand, the next generation vaccine platform includes the use of sequence information of the pathogen. Various vaccine candidates show more or less similar mode of action once entered into the host (Figure 2). Each of the vaccine platforms has some advantages and disadvantages, as listed in table 1 . As of $9^{\text {th }}$ March 2021, there have been 81 vaccines in clinical phase (Table 2) and 182 in pre-clinical phase (World Health Organization, 2021a). As of $18^{\text {th }}$ March 2021, total 392,609,534 vaccine doses have been administered globally ("WHO coronavirus disease (COVID-19) dashboard,” 2021).

\subsection{Live-attenuated vaccine}

It is based on the production of attenuated strain of actual pathogens by in-vitro passaging resulting in limited replication potential of the pathogen which has lost the ability to cause the disease in the host. Also, attenuated strains can be designed by either deleting or mutating the virulence genes in the pathogen. This strategy has been successful in development of various earlier vaccines such as for measles, mumps and chickenpox (Plotkin, 2014). In this line, deletion of virulence factors for generating attenuated strain of SARS-CoV-2 was considered for the development of its vaccine. As of $9^{\text {th }}$ March 2021, there have been only 3 vaccines for SARS-CoV-2 based on this 
strategy (World Health Organization, 2021a). Only 1 vaccine, COVI-VAC, is in clinical phase, developed by Codagenix/Serum Institute of India, and 2 vaccines are in preclinical phases, developed by Mehmet Ali Aydinlar University/Acıbadem Labmed Health Services A.S. and Indian Immunologicals Ltd/Griffith University. COVI-VAC got approval by the Medicines and Healthcare Products Regulatory Agency (MHRA) for phase I trial on $14^{\text {th }}$ Dec, 2020. The study was initiated in London, UK, wherein only a single dose of the vaccine has been administered intranasally which was then evaluated for neutralizing antibodies as well as for cellular immunity in the volunteers. The study aimed to evaluate the safety, tolerability and efficacy of the vaccine. It will also evaluate the immune response with respect to neutralizing antibody, mucosal immunoglobulin $\mathrm{A}$ (IgA) and cellular immune response. COVI-VAC holds great potential as it is a single dose, needle free vaccine which does not require ultra-low temperature for its storage and may induce more robust and long lasting immune response against the pathogen. This vaccine is based on codon deoptimization wherein nucleic acid sequence is altered, leading to usage of suboptimal codons for encoding wild type amino acid sequence. This mechanism slows down the translation of viral protein during infection ("Codagenix and Serum Institute of India announce....... vaccine for COVID-19", 2020). As the vaccine platform utilizes attenuated SARS$\mathrm{CoV}-2$, it may induce more robust and long lasting cellular immune response compared to other vaccine platforms. However, such vaccines require extensive testing for demonstrating its inability to become pathogenic by reverting genetically.

Table 1: Pros and cons of various vaccine platforms used for development of vaccine candidates against viral infections

\begin{tabular}{|l|l|l|l|}
\hline Vaccine Platforms & \multicolumn{1}{|c|}{ Pros } & \multicolumn{1}{c|}{ Cons } \\
\hline $\begin{array}{l}\text { Live-attenuated } \\
\text { Virus }\end{array}$ & $\bullet \begin{array}{l}\text { High potency with low cost } \\
\text { manufacturing }\end{array}$ & $\begin{array}{l}\text { During viral replication, nucleotide } \\
\text { Intrinsic ability to stimulate } \\
\text { innate immune response } \\
\text { production of recombinant strain. } \\
\text { Inactivated Virus }\end{array}$ & $\begin{array}{l}\text { Not suitable for immunocompromised } \\
\text { individuals. }\end{array}$ \\
& $\bullet \begin{array}{l}\text { Can be und safe together with } \\
\text { adjuvant to increase the } \\
\text { immunogenicity } \\
\text { Immunocompromised individuals } \\
\text { can also be vaccinated }\end{array}$ & $\begin{array}{l}\text { Require multiple boosters } \\
\text { Low titre production }\end{array}$ \\
\hline
\end{tabular}




\begin{tabular}{|c|c|c|}
\hline Vaccine Platforms & Pros & Cons \\
\hline Viral Vector & $\begin{array}{l}\text { - Highly specific for gene } \\
\text { delivery in target cells } \\
\text { - May induce robust immune } \\
\text { response } \\
\text { - Increases cellular immunity }\end{array}$ & $\begin{array}{l}\text { - Immunity against vector may } \\
\text { reduce the efficacy } \\
\text { - Probability of integration of viral } \\
\text { genome into the host genome that } \\
\text { may lead to tumorigenesis } \\
\text { - Induces low titre production }\end{array}$ \\
\hline Virus-like particles & $\begin{array}{l}\text { - Can be used with adjuvant to } \\
\text { increase the immunogenicity }\end{array}$ & $\begin{array}{l}\text { - May require multiple boosters } \\
\text { - Low titre production }\end{array}$ \\
\hline DNA-based & $\begin{array}{ll}\text { - } & \text { Stable } \\
\text { - } & \text { Low cost manufacturing } \\
\text { - } & \text { Good safety profile } \\
\text { - } & \text { Infectious viral particles are not } \\
\text { involved }\end{array}$ & $\begin{array}{l}\text { - Low titre production } \\
\text { - May get integrated into host } \\
\text { genome }\end{array}$ \\
\hline RNA-based & $\begin{array}{l}\text { - Low cost and rapid } \\
\text { manufacturing } \\
\text { - Good safety profile } \\
\text { - No risk of viral genome } \\
\text { integration into host genome }\end{array}$ & $\begin{array}{l}\text { - Show instability and thus low } \\
\text { immunogenicity } \\
\text { - May be requiring multiple doses }\end{array}$ \\
\hline Protein Subunit & $\begin{array}{l}\text { - Good safety profile } \\
\text { - Immunocompromised individuals } \\
\text { can also be immunised }\end{array}$ & - Low immunogenicity \\
\hline
\end{tabular}

\subsection{Inactivated virus vaccine}

In this strategy, the viruses are made inactive by employing heat, chemical or irradiation. Such viruses are unlikely to cause pathogenicity and thus show higher safety. These vaccines are able to mount a weak immune response, particularly, humoral immune response, leading to reduced antibody titre. Therefore, such vaccines can be administered with adjuvant in order to increase the immunogenicity and often require repeated boosters to maintain the immunity. It is known to be a well-established platform in the field of vaccine development (Delrue et al., 2012). Various vaccines, based on this platform, have been developed which include vaccines for polio, influenza and rabies with a safe record (Delrue et al., 2012; Murdin et al., 1996; Sabchareon et al., 1999; Vellozzi et al., 2009). For SARS-CoV-2, there have been 10 vaccines in clinical phase and 11 vaccines in preclinical phase as listed by WHO, on $9^{\text {th }}$ march 2021, (World Health Organization, 2021a). Out of 10 vaccines in clinical phase, CoronaVac, developed by Sinovac Research and Development Co., Ltd., is in phase IV of clinical trial. For CoronaVac, the preclinical phases were performed in rats and mice as well as in non-human primates wherein the vaccine showed good immunogenicity. The induced neutralizing antibodies were able to 
neutralise the ten representative strains of SARS-CoV-2. Additionally, the vaccine protected macaques from SARS-CoV-2 without antibody-dependent enhancement. This led to the use of vaccines in the clinical phase in humans (Gao et al., 2020; Zhang et al., 2021). In phase I/II clinical trial in China, a medium dose $(3 \mu \mathrm{g})$ of CoronaVac was found to be effective and well-tolerated which induced neutralizing antibody titre (Wu et al., 2021). The dose-induced geometric mean titre value ranged from 23.8 to 65.4 and 42.2 to 64.4 in 18-59 years and 60 years or above age groups, respectively. However, the T cell response was not assessed in phase I/II trial. The vaccine showed well tolerability with induction of humoral immune response. This humoral response supported the emergency use of CoronaVac in China and simultaneously, the phase III trial is ongoing in Brazil, Turkey and Indonesia. However, the protective efficacy of this vaccine remains undetermined (Wu et al., 2021; Zhang et al., 2021).

\subsection{Virus-like particles}

Virus-like particles are non-infectious molecules which resemble viruses but do not contain any viral genome. Medicago has developed a virus-like particle based vaccine, CoVLP, in collaboration with the government of Quebec and Canada. They also used an adjuvant, manufactured by GlaxoSmithKline (GSK), to enhance the immune response and thereby to reduce the dose of antigen. The clinical phase I was initiated in August, 2020 in Quebec followed by phase II/III in Canada and the United States (National Library of Medicine [NLM]", NCT04450004 (2020); National Library of Medicine [NLM]", NCT04636697 (2021)). In phase I study, three doses were used either adjuvanted or unadjuvanted to assess the safety, tolerability and immunogenicity. The study revealed antibody response which was measured by $\operatorname{IgG}$ and IgM levels. Also, $\mathrm{T}_{\mathrm{H}} 1$ and $\mathrm{T}_{\mathrm{H}} 2$ responses were induced as measured by IFN-Y and IL-4 level, respectively. The phase II/III studies are still ongoing. In addition to this, there are 2 more vaccines based on this strategy, RBD SARS-CoV-2 HBsAg VLP and VBI-2902a, that have been entered into phase I/II of clinical trials. Moreover, there have been 18 virus-like particle based vaccines against SARS-CoV-2 in the pre-clinical phase (World Health Organization, 2021a).

\subsection{Viral vector-based vaccine}

Viral vector-based platforms utilize bioengineered viral backbone of either replicationdeficient or attenuated replication. Such vaccines are known to be highly specific and 
efficient in eliciting a strong immune response (Draper \& Heeney, 2010; Humphreys \& Sebastian, 2018). However, there are several disadvantages with viral vector-based vaccines. For instance, with vaccinia and adenovirus, the generated immune response is against the vectors that consequently lead to reduced efficacy of the vaccine. In contrast, use of lentivirus as well as retrovirus may cause integration of long terminal repeats (LTRs) of virus into the proto-oncogenes resulting in the risk of tumorigenesis in the host (Gaspar et al., 2004). Also, few viral vectors, including adeno-associated virus, give low titre production and thus may not be cost effective (Ura et al., 2014). In spite of such disadvantages, viral vectors are considered to be the most common platform in vaccine development. There have been 19 vaccines in clinical trials and 44 vaccines in preclinical trials against SARS-CoV-2 (World Health Organization, 2021a). The vaccine ChAdOx1-S - (AZD1222) (Covishield), developed by University of Oxford, is in phase IV of clinical evaluation. This vaccine is based on replication-deficient chimpanzee adenoviral vector (ChAdOx1) expressing structural surface glycoprotein (spike protein) of SARS-CoV-2 as an antigen (Voysey et al., 2021). The clinical phase I was initiated in the UK, followed by randomized trials in the UK, Brazil and South Africa. The randomized trial study showed $70.4 \%$ vaccine efficacy after two and at least one standard dose. The study revealed $64.1 \%$ protection against symptomatic disease and thus showed an acceptable safety profile of the vaccine (Voysey et al., 2021).

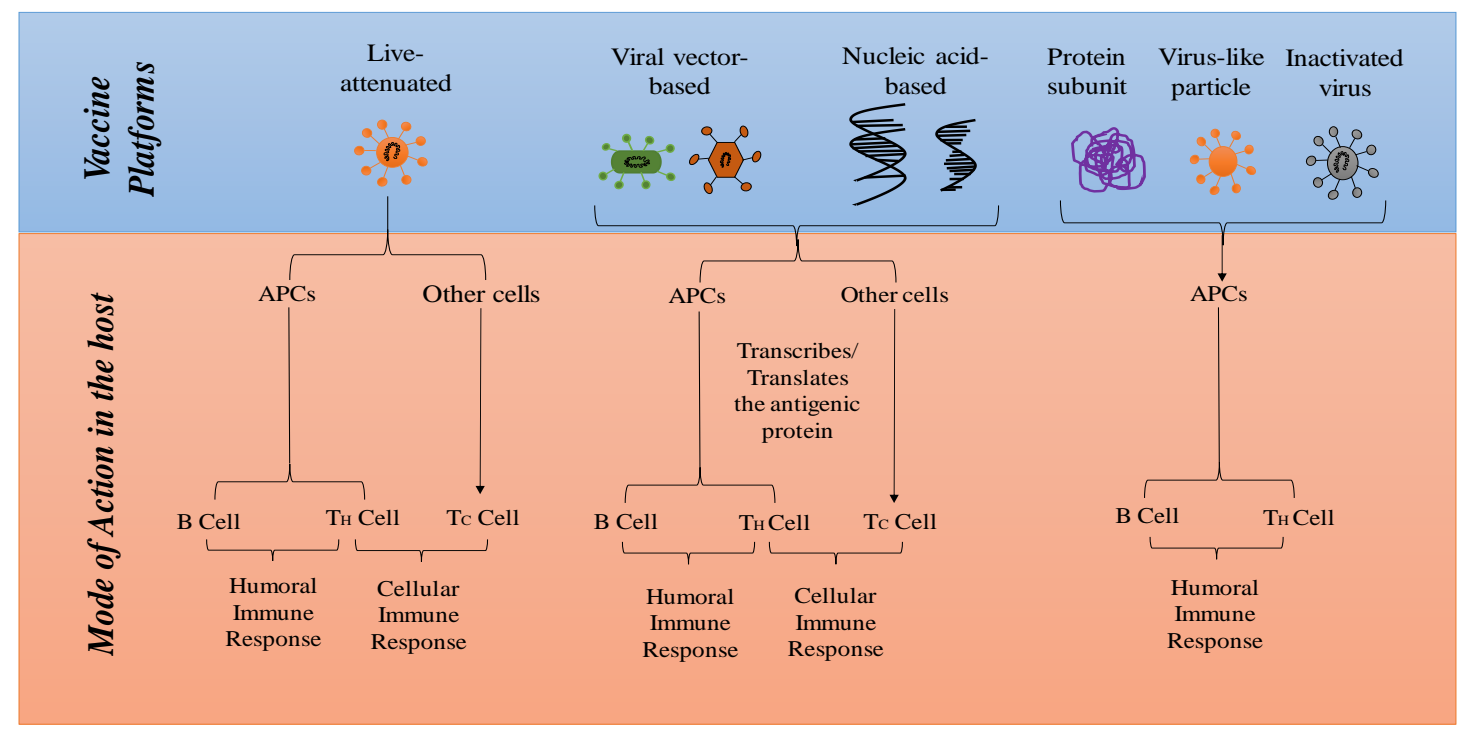

Figure 2: Schematic representation of various vaccine platforms and their mode of action in the host after vaccination. Once the vaccine is inside the host, it may be either taken up by APCs which activate the $B$ cells and $T_{H}$ cells or expressed by vaccinated cells to activate $T_{C}$ cells to induce the killing of virally infected cells. APCs: Antigen presenting cells; other cells represent the vaccinated cells or cells surrounding the vaccinated site. 


\subsection{Nucleic acid-based vaccine}

This represents a potential strategy of the next generation vaccine development platform wherein either DNA or mRNA are used to express the viral antigen in the host. There are several advantages of DNA-based vaccines over the viral vector-based vaccines. For instance, the vectors used in this platform are non-replicating types which carry only the target antigen and thus do not show the risk of diseased condition, as is the case with viral vector-based vaccines (Williams, 2013). The mRNA-based vaccines were the first candidate vaccines that entered into clinical phase development for SARS-CoV-2 infection. The platform exploits lipo-nanoparticles as a delivery agent which also stabilizes its delivery into the cells. There are several advantages of mRNA-based vaccines over the other vaccine platforms. For instance, mRNA-based vaccines are based on viral genome sequence which can be manufactured quickly and thus allow a rapid pathway for its clinical use. Also, mRNA-based vaccines have been shown to generate $\mathrm{T}$ cell response which includes activation of $\mathrm{CD} 4+\mathrm{T}$ cells for antibody production as well as CD8+ T cells for killing of virally-infected cells. Moreover, mRNA-based vaccines are considered to be a more promising approach compared to DNA-based vaccines. With DNA-based vaccines there are chances of DNA vaccines getting integrated into the host genome while mRNA vaccines are single stranded and are not transported to the nucleus while present in cytoplasm only. In view of this, the mRNA-based vaccines are considered to be the potential vaccine platforms which provide better safety norms (Knezevic et al., 2021). The mRNA-based vaccines also show promising potential as indicated by a good safety profile in animal models (Bahl et al., 2017; Pardi et al., 2017). As of $9^{\text {th }}$ March, 2021, there have been 11 DNA-based vaccines in clinical phase while 15 vaccines in pre-clinical phase and mRNA-based 10 vaccines in clinical phase while 23 vaccines in pre-clinical phase, as listed by WHO (World Health Organization, 2021a). Out of them, only 1 DNA-based vaccine, INO4800, has entered into phase III of clinical trial, in contrast, 2 mRNA-based vaccines, mRNA-1273 and BNT162b2 (LNP-mRNAs), have entered into phase IV of clinical trial. The INO-4800 vaccine encodes S protein of SARS-CoV-2. In phase I study, tolerability and immunogenicity of the vaccine were evaluated. The vaccine revealed $15 \%$ and $10 \%$ tolerability with $1 \mathrm{mg}$ and $2 \mathrm{mg}$ dose, respectively. Also, the vaccine elicited either or both humoral and cellular immune response. The geometric mean titre

Vantage: Journal of Thematic Analysis, 2021; 2(1): 42-66 
was found to be 102.3 and 63.5 for $1 \mathrm{mg}$ and $2 \mathrm{mg}$ doses, respectively (Tebas et al., 2021). Moderna in collaboration with National Institute of Allergy and Infectious Diseases (NIAID) developed the mRNA-1273 ("Moderna announces award from U.S. government agency BARDA......against novel coronavirus", 2020). This vaccine encodes S-2P, stabilized pre-fusion spike trimer of SARS-CoV-2, enclosed within lipid nanoparticle. In phase I trial, three doses were evaluated which were administered two times, 28 days apart. The three doses induced geometric mean titre of 40227, 109209 and 213526 in $25 \mu \mathrm{g}, 100 \mu \mathrm{g}$ and $250 \mu \mathrm{g}$ doses, respectively. After second dose of vaccination, the titre value further increased. Out of the three doses, $100 \mu \mathrm{g}$ dose was found to be optimum as it elicited high neutralization response with Th1-skewed CD4 T cell response (Jackson et al., 2020). In phase III trial, the study revealed 94.1\% efficacy of the vaccine against SARS-CoV-2, including severe cases (Baden et al., 2021). BNT162b2 (LNP-mRNAs), developed by Pfizer-BioNTech, an mRNA-based vaccine, encapsulated by lipid nanoparticles, that encodes spike protein mutated at two sites, enabling it to lock in pre-fusion conformation (World Health Organization, 2020b; Polack et al., 2020). In preclinical studies, BNT162b2 showed high humoral as well as cell-mediated immune response in mice and rhesus macaques (Organization, 2020). The clinical phase studies also showed high neutralizing antibody titre with $\mathrm{T}$ cell immune response (Sahin et al., 2020). The two doses $(30 \mu \mathrm{g} /$ dose administered 21 days apart) were found to be safe and effective against SARS-CoV-2 infection. The vaccine showed 95\% efficacy against SARS-CoV-2 infection (Polack et al., 2020).

Table 2: List of various vaccine candidates based on vaccine platforms in clinical phase as listed by WHO (World Health Organization, 2021a)

\begin{tabular}{|c|c|c|c|c|c|}
\hline $\begin{array}{c}\text { Vaccine } \\
\text { platform }\end{array}$ & Vaccine name & Developers & $\begin{array}{c}\text { Number of } \\
\text { doses } / \\
\text { schedule }\end{array}$ & $\begin{array}{c}\text { Route of } \\
\text { administration }\end{array}$ & $\begin{array}{c}\text { Clinical } \\
\text { evaluation }\end{array}$ \\
\hline \multirow{2}{*}{$\begin{array}{c}\text { Virus-like } \\
\text { particles }\end{array}$} & $\begin{array}{c}\text { RBD SARS-CoV-2 } \\
\text { HBsAg VLP }\end{array}$ & $\begin{array}{c}\text { Serum Institute of India } \\
+ \text { Accelagen Pty }+ \\
\text { SpyBiotech }\end{array}$ & $\begin{array}{c}2 \\
(\text { Day } 0+28)\end{array}$ & IM & Phase I/II \\
\cline { 2 - 6 } & CoVLP & Medicago Inc. & $\begin{array}{c}2 \\
(\text { Day } 0+21)\end{array}$ & IM & Phase II/III \\
\hline $\begin{array}{c}\text { Live- } \\
\text { attenuated } \\
\text { virus }\end{array}$ & COVI-VAC & $\begin{array}{c}2 \\
\text { VBI Vaccines Inc. }\end{array}$ & IM 28$)$ & Phase I/II \\
\hline
\end{tabular}




\begin{tabular}{|c|c|c|c|c|c|}
\hline $\begin{array}{l}\text { Vaccine } \\
\text { platform }\end{array}$ & Vaccine name & Developers & $\begin{array}{l}\text { Number of } \\
\text { doses / } \\
\text { schedule }\end{array}$ & $\begin{array}{c}\text { Route of } \\
\text { administration }\end{array}$ & $\begin{array}{c}\text { Clinical } \\
\text { evaluation }\end{array}$ \\
\hline \multirow{9}{*}{$\begin{array}{l}\text { Inactivated } \\
\text { virus }\end{array}$} & CoronaVac & $\begin{array}{l}\text { Sinovac Research and } \\
\text { Development Co., Ltd }\end{array}$ & $\begin{array}{c}2 \\
\text { (Day } 0+14)\end{array}$ & IM & Phase IV \\
\hline & $\begin{array}{l}\text { Inactivated SARS- } \\
\text { CoV-2 (Vero cell) }\end{array}$ & $\begin{array}{c}\text { Sinopharm + China } \\
\text { National Biotec Group } \\
\text { Co + Wuhan Institute } \\
\text { of Biological Products } \\
+ \text { Beijing Institute of } \\
\text { Biological Products }\end{array}$ & $\begin{array}{c}2 \\
(\text { Day } 0+21)\end{array}$ & IM & Phase III \\
\hline & $\begin{array}{l}\text { Inactivated SARS- } \\
\text { CoV-2 (Vero cell) }\end{array}$ & $\begin{array}{c}\text { Institute of Medical } \\
\text { Biology + Chinese } \\
\text { Academy of Medical } \\
\text { Sciences }\end{array}$ & $\begin{array}{c}2 \\
(\text { Day } 0+28)\end{array}$ & IM & Phase III \\
\hline & $\begin{array}{l}\text { Inactivated SARS- } \\
\text { CoV-2 (Vero cell) }\end{array}$ & $\begin{array}{l}\text { Beijing Minhai } \\
\text { Biotechnology Co }\end{array}$ & $\begin{array}{c}1,2 \text { or } 3 \\
\text { (Not } \\
\text { determined) }\end{array}$ & IM & Phase II \\
\hline & $\begin{array}{l}\text { QazCovid-in- } \\
\text { COVID-19 }\end{array}$ & $\begin{array}{l}\text { Research Institute for } \\
\text { Biological Safety } \\
\text { Problems, Rep of } \\
\text { Kazakhstan }\end{array}$ & $\begin{array}{c}2 \\
(\text { Day } 0+21)\end{array}$ & IM & Phase III \\
\hline & BBV152 & $\begin{array}{c}\text { Bharat Biotech } \\
\text { International Limited }\end{array}$ & $\begin{array}{c}2 \\
\text { (Day } 0+14)\end{array}$ & IM & Phase III \\
\hline & VLA2001 & $\begin{array}{l}\text { Valneva, National } \\
\text { Institute for Health } \\
\text { Research, United } \\
\text { Kingdom }\end{array}$ & $\begin{array}{c}2 \\
(\text { Day } 0+21)\end{array}$ & IM & Phase I/II \\
\hline & ERUCOV-VAC & Erciyes University & $\begin{array}{c}2 \\
\text { (Day } 0+21)\end{array}$ & IM & Phase I \\
\hline & $\begin{array}{c}\text { COVID-19 } \\
\text { inactivated vaccine }\end{array}$ & $\begin{array}{l}\text { Shifa Pharmed } \\
\text { Industrial Co }\end{array}$ & $\begin{array}{c}2 \\
\text { (Day } 0+14)\end{array}$ & IM & Phase I \\
\hline \multirow{4}{*}{$\begin{array}{l}\text { Viral vector } \\
\text { (replicating) }\end{array}$} & $\begin{array}{l}\text { DelNS1-2019-nCoV- } \\
\text { RBD-OPT1 }\end{array}$ & $\begin{array}{c}\text { University of Hong } \\
\text { Kong, Xiamen } \\
\text { University and Beijing } \\
\text { Wantai Biological } \\
\text { Pharmacy }\end{array}$ & $\begin{array}{c}1 \\
\text { (Day 0) }\end{array}$ & IN & Phase II \\
\hline & $\begin{array}{c}\text { rVSV-SARS-CoV-2- } \\
\text { S }\end{array}$ & $\begin{array}{l}\text { Israel Institute for } \\
\text { Biological Research }\end{array}$ & $\begin{array}{c}1 \\
\text { (Day 0) }\end{array}$ & IM & Phase I/II \\
\hline & AdCLD-CoV19 & Cellid Co., Ltd. & $\begin{array}{c}1 \\
\text { (Day 0) }\end{array}$ & IM & Phase I/II \\
\hline & NDV-HXP-S & $\begin{array}{l}\text { Mahidol University; } \\
\text { The Government } \\
\text { Pharmaceutical } \\
\text { Organization (GPO); } \\
\text { Icahn School of } \\
\text { Medicine at Mount } \\
\text { Sinai }\end{array}$ & $\begin{array}{c}2 \\
(\text { Day } 0+28)\end{array}$ & IM & Phase I/II \\
\hline \multirow[b]{2}{*}{$\begin{array}{l}\text { Viral vector } \\
\text { (replicating) } \\
\quad+\text { APC }\end{array}$} & COVID-19/aAPC & $\begin{array}{l}\text { Shenzhen Geno- } \\
\text { Immune Medical } \\
\text { Institute }\end{array}$ & $\begin{array}{c}3 \\
(\text { Day } 0+14 \\
+28)\end{array}$ & SC & Phase I \\
\hline & AV-COVID-19 & $\begin{array}{c}\text { Aivita Biomedical, Inc. } \\
\text { National Institute of } \\
\text { Health Research and } \\
\text { Development, Ministry } \\
\text { of Health Republic of } \\
\text { Indonesia }\end{array}$ & $\begin{array}{c}1 \\
\text { (Day 0) }\end{array}$ & IM & Phase I/II \\
\hline
\end{tabular}




\begin{tabular}{|c|c|c|c|c|c|}
\hline $\begin{array}{l}\text { Vaccine } \\
\text { platform }\end{array}$ & Vaccine name & Developers & $\begin{array}{l}\text { Number of } \\
\text { doses / } \\
\text { schedule }\end{array}$ & $\begin{array}{c}\text { Route of } \\
\text { administration }\end{array}$ & $\begin{array}{c}\text { Clinical } \\
\text { evaluation }\end{array}$ \\
\hline \multirow{12}{*}{$\begin{array}{l}\text { Viral vector } \\
\quad \text { (non- } \\
\text { replicating) }\end{array}$} & $\begin{array}{l}\text { ChAdOx1-S - } \\
\text { (AZD1222) } \\
\text { (Covishield) }\end{array}$ & $\begin{array}{c}\text { AstraZeneca }+ \\
\text { University of Oxford }\end{array}$ & $\begin{array}{c}1-2 \\
(\text { Day } 0+28)\end{array}$ & IM & Phase IV \\
\hline & $\begin{array}{l}\text { Recombinant novel } \\
\text { coronavirus vaccine }\end{array}$ & $\begin{array}{l}\text { CanSino Biological } \\
\text { Inc./Beijing Institute of } \\
\text { Biotechnology }\end{array}$ & $\begin{array}{c}1 \\
(\text { Day } 0)\end{array}$ & $\mathrm{IM}$ & Phase III \\
\hline & rAd26-S+rAd5-S & $\begin{array}{l}\text { Gamaleya Research } \\
\text { Institute; Health } \\
\text { Ministry of the Russian } \\
\text { Federation }\end{array}$ & $\begin{array}{c}2 \\
(\text { Day } 0+21)\end{array}$ & $\mathrm{IM}$ & Phase III \\
\hline & Ad26.COV2.S & Janssen Pharmaceutical & $\begin{array}{c}1-2 \\
\text { (Day } 0 \text { or } \\
\text { Day } 0+56)\end{array}$ & $\mathrm{IM}$ & Phase III \\
\hline & GRAd-COV2 & $\begin{array}{l}\text { ReiThera + Leukocare } \\
+ \text { Univercells }\end{array}$ & $\begin{array}{c}1 \\
\text { (Day 0) }\end{array}$ & IM & Phase I \\
\hline & VXA-CoV2-1 Ad5 & Vaxart & $\begin{array}{c}2 \\
(\text { Day } 0+28)\end{array}$ & Oral & Phase I \\
\hline & MVA-SARS-2-S & $\begin{array}{l}\text { University of Munich } \\
\text { (Ludwig-Maximilians) }\end{array}$ & $\begin{array}{c}2 \\
(\text { Day } 0+28)\end{array}$ & IM & Phase I \\
\hline & $\begin{array}{c}\text { hAd5 S+N vaccine } \\
(\text { S-Fusion }+\mathrm{N}- \\
\text { ETSD })\end{array}$ & $\begin{array}{l}\text { ImmunityBio, Inc. \& } \\
\text { NantKwest, Inc. }\end{array}$ & $\begin{array}{c}1-2 \\
(\text { Day } 0+21)\end{array}$ & SC or Oral & Phase I \\
\hline & $\begin{array}{l}\text { COH04S1 (MVA- } \\
\text { SARS-2-S) - } \\
\text { Modified vaccinia } \\
\text { ankara (sMVA) } \\
\text { platform + synthetic } \\
\text { SARS-CoV-2 }\end{array}$ & $\begin{array}{c}\text { City of Hope Medical } \\
\text { Center + National } \\
\text { Cancer Institute }\end{array}$ & $\begin{array}{c}1-2 \\
(\text { Day } 0+28)\end{array}$ & IM & Phase I \\
\hline & AdCOVID & Altimmune, Inc. & $\begin{array}{c}1-2 \\
(\text { Day } 0)\end{array}$ & IN & Phase I \\
\hline & BBV154 & $\begin{array}{c}\text { Bharat Biotech } \\
\text { International Limited }\end{array}$ & $\begin{array}{c}1 \\
\text { (Day 0) }\end{array}$ & IN & Phase I \\
\hline & $\begin{array}{c}\text { Chimpanzee } \\
\text { Adenovirus serotype } \\
68 \text { (ChAd) and self- } \\
\text { amplifying mRNA } \\
\text { (SAM) vectors } \\
\text { expressing spike } \\
\text { alone, or spike plus } \\
\text { additional SARS- } \\
\text { CoV-2 T cell } \\
\text { epitopes. }\end{array}$ & Gritstone Oncology & $\begin{array}{c}2-3 \\
(\text { Day } 0+14 \\
+28 \text { or Day } \\
0+28+56 \\
\text { or Day } 0+ \\
112)\end{array}$ & IM & Phase I \\
\hline $\begin{array}{l}\text { Viral vector } \\
\text { (non- } \\
\text { replicating) } \\
\text { + APC }\end{array}$ & LV-SMENP-DC & $\begin{array}{l}\text { Shenzhen Geno- } \\
\text { Immune Medical } \\
\text { Institute }\end{array}$ & $\begin{array}{c}1 \\
(\text { Day } 0)\end{array}$ & SC and IV & Phase I/II \\
\hline
\end{tabular}




\begin{tabular}{|c|c|c|c|c|c|}
\hline $\begin{array}{l}\text { Vaccine } \\
\text { platform }\end{array}$ & Vaccine name & Developers & $\begin{array}{l}\text { Number of } \\
\text { doses / } \\
\text { schedule }\end{array}$ & $\begin{array}{c}\text { Route of } \\
\text { administration }\end{array}$ & $\begin{array}{c}\text { Clinical } \\
\text { evaluation }\end{array}$ \\
\hline \multirow{16}{*}{$\begin{array}{l}\text { Protein sub- } \\
\text { unit }\end{array}$} & NVX-CoV2373 & Novavax & $\begin{array}{c}2 \\
(\text { Day } 0+21)\end{array}$ & IM & Phase III \\
\hline & CHO Cell & $\begin{array}{c}\text { Anhui Zhifei Longcom } \\
\text { Biopharmaceutical + } \\
\text { Institute of } \\
\text { Microbiology, Chinese } \\
\text { Academy of Sciences }\end{array}$ & $\begin{array}{c}2-3 \\
(\text { Day } 0+28 \\
\text { or Day } 0+ \\
28+56)\end{array}$ & $\mathrm{IM}$ & Phase III \\
\hline & KBP-COVID-19 & $\begin{array}{c}\text { Kentucky } \\
\text { Bioprocessing Inc. }\end{array}$ & $\begin{array}{c}2 \\
(\text { Day } 0+21)\end{array}$ & IM & Phase I/II \\
\hline & $\begin{array}{l}\text { SARS-CoV-2 vaccine } \\
\text { formulation } 1 \text { with } \\
\text { adjuvant } 1 \text { ( } \mathrm{S} \text { protein }\end{array}$ & Sanofi Pasteur + GSK & $\begin{array}{c}2 \\
(\text { Day } 0+21)\end{array}$ & IM & Phase I/II \\
\hline & $\begin{array}{l}\text { SCB-2019 + AS03 } \\
\quad \text { or CpG } 1018\end{array}$ & $\begin{array}{c}\text { Clover } \\
\text { Biopharmaceuticals } \\
\text { Inc./GSK/Dynavax }\end{array}$ & $\begin{array}{c}2 \\
(\text { Day } 0+21)\end{array}$ & IM & Phase II/III \\
\hline & COVAX-19 & Vaxine Pty Ltd. & $\begin{array}{c}1 \\
\text { (Day 0) }\end{array}$ & IM & Phase I \\
\hline & $\begin{array}{c}\text { MVC-COV1901 } \\
(\mathrm{S}-2 \mathrm{P} \text { protein }+\mathrm{CpG} \\
1018)\end{array}$ & $\begin{array}{c}\text { Medigen Vaccine } \\
\text { Biologics + Dynavax }+ \\
\text { National Institute of } \\
\text { Allergy and Infectious } \\
\text { Diseases (NIAID) }\end{array}$ & $\begin{array}{c}2 \\
(\text { Day } 0+28)\end{array}$ & IM & Phase II \\
\hline & FINLAY-FR1 & $\begin{array}{c}\text { Instituto Finlay de } \\
\text { Vacunas }\end{array}$ & $\begin{array}{c}2 \\
(\text { Day } 0+28)\end{array}$ & IM & Phase I/II \\
\hline & FINLAY-FR-2 & $\begin{array}{c}\text { Instituto Finlay de } \\
\text { Vacunas }\end{array}$ & $\begin{array}{c}2 \\
(\text { Day } 0+28)\end{array}$ & IM & Phase II \\
\hline & EpiVacCorona & $\begin{array}{c}\text { Federal Budgetary } \\
\text { Research Institution State } \\
\text { Research Center of } \\
\text { Virology and } \\
\text { Biotechnology "Vector" }\end{array}$ & $\begin{array}{c}2 \\
(\text { Day } 0+21)\end{array}$ & IM & Phase I/II \\
\hline & $\begin{array}{l}\text { Recombinant SARS- } \\
\text { CoV-2 vaccine (Sf9 } \\
\text { Cell) }\end{array}$ & $\begin{array}{l}\text { West China Hospital + } \\
\text { Sichuan University }\end{array}$ & $\begin{array}{c}2 \\
(\text { Day } 0+28)\end{array}$ & IM & Phase II \\
\hline & IMP CoVac-1 & $\begin{array}{c}\text { University Hospital } \\
\text { Tuebingen }\end{array}$ & $\begin{array}{c}1 \\
\text { (Day 0) }\end{array}$ & $\mathrm{SC}$ & Phase I \\
\hline & UB-612 & $\begin{array}{l}\text { COVAXX + United } \\
\text { Biomedical Inc }\end{array}$ & $\begin{array}{c}2 \\
\text { (Day } 0+28)\end{array}$ & IM & Phase II/III \\
\hline & AdimrSC-2f & $\begin{array}{l}\text { Adimmune } \\
\text { Corporation1 }\end{array}$ & ND & ND & Phase I \\
\hline & $\begin{array}{c}\text { CIGB-669 } \\
(\mathrm{RBD}+\mathrm{AgnHB})\end{array}$ & $\begin{array}{c}\text { Center for Genetic } \\
\text { Engineering and } \\
\text { Biotechnology (CIGB) }\end{array}$ & $\begin{array}{c}3 \\
\text { (Day } 0+14 \\
+28 \text { or } \\
\text { Day } 0+28+ \\
56)\end{array}$ & IN & Phase I/II \\
\hline & $\begin{array}{c}\text { CIGB-66 } \\
\text { (RBD+aluminium } \\
\text { hydroxide) }\end{array}$ & $\begin{array}{c}\text { Center for Genetic } \\
\text { Engineering and } \\
\text { Biotechnology (CIGB) }\end{array}$ & $\begin{array}{c}3 \\
(\text { Day } 0+14 \\
+28 \text { or } \\
\text { Day } 0+28+ \\
56)\end{array}$ & IM & Phase I/II \\
\hline
\end{tabular}




\begin{tabular}{|c|c|c|c|c|c|}
\hline $\begin{array}{l}\text { Vaccine } \\
\text { platform }\end{array}$ & Vaccine name & Developers & $\begin{array}{c}\text { Number of } \\
\text { doses / } \\
\text { schedule }\end{array}$ & $\begin{array}{c}\text { Route of } \\
\text { administration }\end{array}$ & $\begin{array}{c}\text { Clinical } \\
\text { evaluation }\end{array}$ \\
\hline & BECOV2 & Biological E. Limited & $\begin{array}{c}2 \\
(\text { Day } 0+28)\end{array}$ & IM & Phase I/II \\
\hline & $\begin{array}{l}\text { Recombinant Sars- } \\
\text { CoV-2 Spike protein, } \\
\text { Aluminum } \\
\text { adjuvanted }\end{array}$ & $\begin{array}{c}\text { Nanogen } \\
\text { Pharmaceutical } \\
\text { Biotechnology }\end{array}$ & $\begin{array}{c}2 \\
(\text { Day } 0+21)\end{array}$ & IM & Phase I/II \\
\hline & S-268019 & Shionogi & $\begin{array}{c}2 \\
(\text { Day } 0+21)\end{array}$ & IM & Phase I/II \\
\hline & $\begin{array}{l}\text { SARS-CoV-2-RBD- } \\
\text { Fc fusion protein }\end{array}$ & $\begin{array}{c}\text { University Medical } \\
\text { Center Groningen + } \\
\text { Akston Biosciences Inc. }\end{array}$ & & SC or IM & Phase I/II \\
\hline & $\begin{array}{l}\text { COVAC }-1 \text { and } \\
\text { COVAC- }-2\end{array}$ & $\begin{array}{l}\text { University of } \\
\text { Saskatchewan }\end{array}$ & $\begin{array}{c}2 \\
(\text { Day } 0+28)\end{array}$ & IM & Phase I/II \\
\hline & GBP510 & $\begin{array}{l}\text { SK Bioscience Co., } \\
\text { Ltd. }\end{array}$ & $\begin{array}{c}2 \\
(\text { Day } 0+28)\end{array}$ & IM & Phase I/II \\
\hline & Razi Cov Pars & $\begin{array}{l}\text { Razi Vaccine and } \\
\text { Serum Research } \\
\text { Institute }\end{array}$ & $\begin{array}{c}3 \\
(\text { Day } 0+21 \\
+51)\end{array}$ & IM and IN & Phase I \\
\hline & $\begin{array}{l}\text { MF59 adjuvanted } \\
\text { SARS-CoV-2 } \\
\text { Sclamp }\end{array}$ & $\begin{array}{c}\text { The University of } \\
\text { Queensland }\end{array}$ & $\begin{array}{c}2 \\
(\text { Day } 0+28)\end{array}$ & IM & Phase I \\
\hline & $\begin{array}{l}\text { SpFN (Spike- } \\
\text { Ferritin- } \\
\text { Nanoparticle) }\end{array}$ & $\begin{array}{l}\text { Walter Reed Army } \\
\text { Institute of Research } \\
\text { (WRAIR) }\end{array}$ & $\begin{array}{c}2-3 \\
(\text { Day } 0+28 \\
+180)\end{array}$ & IM & Phase I \\
\hline & $\begin{array}{l}\text { NBP2001 + } \\
\text { adjuvanted with } \\
\text { alum. }\end{array}$ & SK Bioscience Co., Ltd & $\begin{array}{c}2 \\
(\text { Day } 0+28)\end{array}$ & IM & Phase I \\
\hline & EuCorVac-19 & EuBiologics Co.,Ltd & $\begin{array}{c}2 \\
(\text { Day } 0+21)\end{array}$ & IM & Phase I/II \\
\hline \multirow{7}{*}{$\begin{array}{l}\text { Nucleic acid } \\
\text { (RNA- } \\
\text { based) }\end{array}$} & mRNA-1273 & $\begin{array}{l}\text { Moderna + National } \\
\text { Institute of Allergy and } \\
\text { Infectious Diseases } \\
\text { (NIAID) }\end{array}$ & $\begin{array}{c}2 \\
(\text { Day } 0+28)\end{array}$ & IM & Phase IV \\
\hline & $\begin{array}{c}\text { BNT162 (3 LNP- } \\
\text { mRNAs) }\end{array}$ & $\begin{array}{c}\text { Pfizer/BioNTech + } \\
\text { Fosun Pharma }\end{array}$ & $\begin{array}{c}2 \\
(\text { Day } 0+21)\end{array}$ & IM & Phase IV \\
\hline & $\mathrm{CVnCoV}$ & CureVac AG & $\begin{array}{c}2 \\
\text { (Day } 0+28)\end{array}$ & IM & Phase III \\
\hline & ARCT-021 & Arcturus Therapeutics & ND & IM & Phase II \\
\hline & LNP-nCoVsaRNA & $\begin{array}{l}\text { Imperial College } \\
\text { London }\end{array}$ & ND & IM & Phase I \\
\hline & ARCoV & $\begin{array}{l}\text { Academy of Military } \\
\text { Science (AMS), } \\
\text { Walvax Biotechnology } \\
\text { and Suzhou Abogen } \\
\text { Biosciences }\end{array}$ & $\begin{array}{c}2 \\
(\text { Day } 0+14 \\
\text { or } \\
\text { Day } 0+28)\end{array}$ & IM & Phase I \\
\hline & ChulaCov19 mRNA & $\begin{array}{l}\text { Chulalongkorn } \\
\text { University }\end{array}$ & $\begin{array}{c}2 \\
(\text { Day } 0+21)\end{array}$ & IM & Phase I \\
\hline
\end{tabular}




\begin{tabular}{|c|c|c|c|c|c|}
\hline $\begin{array}{l}\text { Vaccine } \\
\text { platform }\end{array}$ & Vaccine name & Developers & $\begin{array}{c}\text { Number of } \\
\text { doses / } \\
\text { schedule }\end{array}$ & $\begin{array}{c}\text { Route of } \\
\text { administration }\end{array}$ & $\begin{array}{c}\text { Clinical } \\
\text { evaluation }\end{array}$ \\
\hline & PTX-COVID19-B & $\begin{array}{l}\text { Providence } \\
\text { Therapeutics }\end{array}$ & $\begin{array}{c}2 \\
(\text { Day } 0+28)\end{array}$ & IM & Phase I \\
\hline & CoV2 SAM (LNP) & GlaxoSmithKline & $\begin{array}{c}2 \\
(\text { Day } 0+28)\end{array}$ & IM & Phase I \\
\hline & mRNA-1273.351 & $\begin{array}{c}\text { Moderna + National } \\
\text { Institute of Allergy and } \\
\text { Infectious Diseases } \\
\text { (NIAID) }\end{array}$ & $\begin{array}{c}3 \\
\text { (Day 0 or } \\
\text { Day 0 } 0+28 \\
\text { or Day 56) }\end{array}$ & IM & Phase I \\
\hline \multirow{10}{*}{$\begin{array}{l}\text { Nucleic acid } \\
\text { (DNA- } \\
\text { based) }\end{array}$} & $\begin{array}{c}\text { INO- } \\
4800+\text { electroporation }\end{array}$ & $\begin{array}{c}\text { Inovio Pharmaceuticals } \\
\text { + International Vaccine } \\
\text { Institute + Advaccine } \\
\text { (Suzhou) } \\
\text { Biopharmaceutical Co., } \\
\text { Ltd }\end{array}$ & $\begin{array}{c}2 \\
(\text { Day } 0+28)\end{array}$ & ID & Phase II/III \\
\hline & AG0301-COVID19 & $\begin{array}{c}\text { AnGes + Takara Bio + } \\
\text { Osaka University }\end{array}$ & $\begin{array}{c}2 \\
(\text { Day } 0+14)\end{array}$ & IM & Phase II/III \\
\hline & $\mathrm{nCov}$ & Zydus Cadila & $\begin{array}{c}3 \\
(\text { Day } 0+28 \\
+56)\end{array}$ & ID & Phase III \\
\hline & GX-19 & Genexine Consortium & $\begin{array}{c}2 \\
(\text { Day } 0+28)\end{array}$ & IM & Phase I/II \\
\hline & Covigenix VAX-001 & $\begin{array}{l}\text { Entos Pharmaceuticals } \\
\text { Inc. }\end{array}$ & $\begin{array}{c}2 \\
(\text { Day } 0+14)\end{array}$ & IM & Phase I \\
\hline & CORVax & $\begin{array}{c}\text { Providence Health \& } \\
\text { Services }\end{array}$ & $\begin{array}{c}2 \\
(\text { Day } 0+14)\end{array}$ & ID & Phase I \\
\hline & $\begin{array}{c}\text { bacTRL-Spike oral } \\
\text { DNA }\end{array}$ & Symvivo Corporation & $\begin{array}{c}1 \\
\text { (Day 0) }\end{array}$ & Oral & Phase I \\
\hline & GLS-5310 & $\begin{array}{l}\text { GeneOne Life Science, } \\
\text { Inc. }\end{array}$ & $\begin{array}{c}2 \\
(\text { Day } 0+56 \\
\text { or } \\
\text { Day } 0+84)\end{array}$ & ID & Phase I/II \\
\hline & COVIGEN & $\begin{array}{l}\text { University of Sydney, } \\
\text { Bionet Co., Ltd } \\
\text { Technovalia }\end{array}$ & $\begin{array}{c}2 \\
(\text { Day } 0+28)\end{array}$ & IM & Phase I \\
\hline & COVID-eVax & $\begin{array}{c}\text { Takis and Rottapharm } \\
\text { Biotech }\end{array}$ & & IM & Phase I/II \\
\hline
\end{tabular}

\subsection{Protein subunit-based vaccine}

The protein subunit platform utilizes either the synthetic peptides or the recombinant antigenic protein to elicit a strong immune response in the host. Such vaccines exhibit low immunogenicity and thus require repeated boosters with an adjuvant to enhance the immune response (Wang et al., 2020). However, the protein component, if denatured, may bind to different antibodies in the vaccinated individual and thereby lead to lack of efficacy (Organization, 2020a). For development of COVID-19 
vaccine based on this platform, researchers have used the spike (S) protein, one of the structural proteins of SARS-COV-2. The SARS-COV-2 infection initiates at the respiratory tract wherein the virus interacts with angiotensin-converting enzyme 2 (ACE 2) receptor present on alveolar and bronchial epithelial cells via viral S protein (Ou et al., 2020). In this line, some have used full length $S$ protein while some have utilised a portion of it, in order to induce enhanced titre of neutralizing antibodies (Wang et al., 2020). As of $9^{\text {th }}$ March, 2021, there have been 27 vaccines in the clinical phase while 68 vaccines in the preclinical phase (World Health Organization, 2021a). One of the candidate vaccines that has been developed based on this platform is NVX-CoV2373, developed by Novavax. It is a nanoparticle-based vaccine wherein full length recombinant SARS-CoV-2 glycoprotein has been adjuvanted with matrix M. Its clinical phaseI/II trial revealed its safety and an elicited immune response. Also, the adjuvant induced Th1-biased CD4+ T cell response (Keech et al., 2020). The NVX-CoV2373 has been evaluated for its strong efficacy in two phase III trials conducted in the UK and Mexico (COVID-19). The vaccine showed 60\% and 89.3\% efficacy in phase IIb trial in South Africa and phase III trial in UK, respectively ("Novavax COVID-19 vaccine demonstrates $89.3 \%$ efficacy in UK phase 3 trial", 2021). However, it has not yet entered into phase IV clinical trials.

Besides considering these various platforms, route of administration is emerging as an important aspect during vaccination. Various routes of vaccine administration have been considered such as intramuscular, intradermal, subcutaneous, oral and intranasal. Majority of the vaccines that have entered into the clinical phase against COVID-19, are being administered intramuscularly. However, researchers suggest that intramuscularly injected vaccines induce $\operatorname{IgG}$ production in the blood, on the other hand, nasal vaccines also induce IgA production by the mucosa. Also, the nasal vaccines can stimulate various other mucosal sites within the host. As COVID-19 spread occurs through airways, so even if the viral infection has left the lungs, it could be present in the nose. Thus, there are chances of viral spread even after vaccination. Therefore, nasal vaccines represent an easy and efficient route of vaccine administration in the host (Mageit, 2021). In view of this, few vaccines have entered into clinical phase which include CIGB-66 (phase I/II trial) developed by Center for 
Genetic Engineering and Biotechnology (CIGB), AdCOVID (phase I trial) developed by Altimmune, BBV154 (phase I trial) developed by Bharat Biotech International Limited, DelNS1-2019-nCoV-RBD-OPT1 (phase II) developed by University of Hong Kong, Xiamen University and Beijing Wantai Biological Pharmacy and COVIVAC (phase I) developed by Codagenix/Serum Institute of India. These vaccines are based on different vaccine platforms while sharing the same route of administration (Table 2).

\section{VACCINE STATUS IN INDIA}

In India, the first confirmed case of COVID-19 was reported on $30^{\text {th }}$ January, 2020, in Kerala. The patient had returned from Wuhan, China (Andrews et al., 2020). Thereafter, more and more cases were reported which then spread to other states of India. As on $21^{\text {st }}$ March, 2021, there have been a total of 11,599,130 confirmed cases out of which 11,130,288 cases showed recovery, 159,755 died and 3,09,087 cases have been active cases. The number has been increasing day by day with some states (Maharashtra, Kerala, Punjab, Karnataka, Gujarat and Tamil Nadu) reporting a high number of cases as stated by the Health Ministry ("Coronavirus outbreak", 2021).

To immunize more than 1.3 billion population of India against COVID-19, the vaccination programme was initiated on $16^{\text {th }}$ January, 2021. To run the massive programme of vaccination, the experts decoded the process for who will get the vaccine first and how one can register (Bhatia, 2021). According to the process, in the first phase, free vaccines will be given to one crore healthcare workers in government as well as in private hospitals. Thereafter, around two crores frontline warriors and municipal workers will be vaccinated which will also include the workers of state government and ministries. Then, people over 50 years of age, followed by people in identified priority areas with high COVID-19 infection and then to the people with comorbid conditions. This will be followed by the vaccination of the rest of the population (Bhatia, 2021). India's drug regulators approved two COVID-19 vaccines, Covishield and Covaxin, for emergency use in India. Covishield is an OxfordAstraZeneca vaccine which is being manufactured by Serum Institute of India (SII). The vaccine is based on a vector-based platform wherein weakened version of the common cold virus from chimpanzees has been utilised. The vaccine is administered

Vantage: Journal of Thematic Analysis, 2021; 2(1): 42-66 
in two doses and can be stored at $2-8^{0} \mathrm{C}$ safely. The phase 3 clinical trial of Covishield has been conducted by SII, co-sponsored by Indian Council of Medical Research (ICMR), in India. Based on clinical studies, in the UK, Brazil and India, Covishield was found to be safe and well-tolerated against severe infection of COVID-19 ("Serum Institute seeks emergency use authorisation for Oxford COVID19 vaccine Covishield in India," 2020). On the other hand, Covaxin is an indigenous vaccine of India developed by Bharat Biotech in collaboration with ICMR- National Institute of Virology (NIV). It has been manufactured in BSL-3 (Bio-safety level 3) high containment facility of Bharat Biotech and is based on the inactivated virus platform of vaccine development. Covaxin is being administered with an adjuvant to increase the immunogenicity of vaccines. The vaccine is stable at $2-8^{\circ} \mathrm{C}$ with no reconstitution requirement. The pre-clinical studies for this vaccine have been performed on hamsters and non-human primates which showed strong immunogenicity and protective efficacy. In phase I clinical trial, 375 participants were enrolled to assess the safety and immunogenicity of vaccines in humans. The study showed tolerable safety outcomes with enhanced immune response and no adverse effects. Moreover, humoral as well as cell-mediated immune responses were elicited in the participants (Ella et al., 2021). Similarly, in phase II study, wherein 380 participants were enrolled, enhanced humoral and cell-mediated immune responses were observed. In phase III trial, 25,800 participants were enrolled and the study demonstrated $81 \%$ interim efficacy against COVID-19 in individuals without prior infection after the second dose ("COVAXIN- India's first indigenous COVID-19 vaccine", 2021). As of $20^{\text {th }}$ March, 2021, 3,71,25,187 individuals have been vaccinated with the first dose of vaccine that included health care and frontline workers while 74,78,654 have been given a second dose of the vaccine. So, a total of 4,46,03,841 doses have been administered ("Vaccination update," 2021). Various other countries are also approaching for the procurement of both the vaccines. India has exported 58 million doses of vaccines to various countries, either in the form of gifts or in line with the signed agreements between recipient countries and vaccine makers. Also, some have been supplied under the Covax scheme, led by WHO. It was stated by the Foreign Ministry that based on domestic requirements and international demands and obligations, India will supply the vaccines all over the world 
("Covishield and Covaxin: What we know about India's COVID-19 vaccine," 2021). In addition to these two vaccines, there are other vaccine candidates (ZyCov-Di, HGCO19, Sputnik V and other vaccines being developed by Hyderabad-based Biological E, nasal vaccine by Bharat Biotech and a second vaccine by SII and Novavax) which are in different phases of trials for checking their safety and efficacy (“Covishield and Covaxin: What we know about India's COVID-19 vaccine," 2021).

\section{CONCLUSION}

The emergence of SARS-CoV-2 infection, has led to the termination of the global economy. Scientists all around the world are joining hands to control the exponentially increasing rate of COVID-19. Various vaccine platforms have been exploited in parallel, with overlapping pre-clinical and clinical phases. This has also accelerated the manufacturing process; however, there is still a need to speed up the process. With the current status of COVID-19 cases, it seems that the vaccine development process will continue for the next few years until more and more vaccines would enter into emergency use authorization.

\section{CONFLICT OF INTEREST}

The authors declare no conflict of interest.

\section{REFERENCES}

Andrews, M., Areekal, B., Rajesh, K., Krishnan, J., Suryakala, R., Krishnan, B., Muraly, C., \& Santhosh, P. (2020). First confirmed case of COVID-19 infection in India: A case report. The Indian Journal of Medical Research, 151(5), 490-491. DOI: 10.4103/ijmr.IJMR_2131_20

Bahl, K., Senn, J. J., Yuzhakov, O., Bulychev, A., Brito, L. A., Hassett, K. J., Laska, M. E., Smith, M., Almarsson, Ö., \& Thompson, J. (2017). Preclinical and clinical demonstration of immunogenicity by mRNA vaccines against H10N8 and H7N9 influenza viruses. Molecular Therapy, 25(6), 1316-1327.

Baden, L. R., El Sahly, H.M., Essink, B., Kotloff, K., Frey, S., Novak, R., \& Zaks, T. (2021). Efficacy and safety of the mRNA-1273 SARS-CoV-2 vaccine. The New England Journal of Medicine, 384(5), 403-416. DOI: 10.1056/NEJMoa2035389

Vantage: Journal of Thematic Analysis, 2021; 2(1): 42-66 
Bhatia, A. (2021, January 6). India's COVID vaccination programme explained: Who will get it first, what is the process and other things you need to know. Retrieved from https://swachhindia.ndtv.com/indias-covid-vaccination-programme-explained-whowill-get-it-first-what-is-the-process-and-other-things-you-need-to-know-54989/

Blanco-Melo, D., Nilsson-Payant, B. E., Liu, W.-C., Uhl, S., Hoagland, D., Møller, R., Jordan, T. X., Oishi, K., Panis, M., \& Sachs, D. (2020). Imbalanced host response to SARS-CoV-2 drives development of COVID-19. Cell, 181(5), 1036-1045. e1039.

Codagenix and Serum Institute of India announce commencement of first-in-human trial of COVI-VAC, a single dose, intranasal live attenuated vaccine for COVID-19. (2020, December 14). Retrieved from https://www.prnewswire.com/newsreleases/codagenix-and-serum-institute-of-india-announce-commencement-offirst-in-human-trial-of-covi-vac-a-single-dose-intranasal-live-attenuated-vaccinefor-covid-19-301191756.html

Coronavirus outbreak. (2021, March, 21). Retrieved from https://www.ndtv.com/ coronavirus/fullcoverage

COVAXIN- India's first indigenous COVID-19 vaccine. (2021). Retrieved from https://www.bharatbiotech.com/covaxin.html

Covishield and Covaxin: What we know about India's Covid-19 vaccine. (2021, March 9). Retrieved from https://www.bbc.com/news/world-asia-india55748124

Delrue, I., Verzele, D., Madder, A., \& Nauwynck, H. J. (2012). Inactivated virus vaccines from chemistry to prophylaxis: merits, risks and challenges. Expert review of vaccines, 11(6), 695-719.

Dowd, K. A., \& Pierson, T. C. (2011). Antibody-mediated neutralization of flaviviruses: a reductionist view. Virology, 411(2), 306-315.

Draper, S. J., \& Heeney, J. L. (2010). Viruses as vaccine vectors for infectious diseases and cancer. Nature reviews Microbiology, 8(1), 62-73.

Vantage: Journal of Thematic Analysis, 2021; 2(1): 42-66 
Ella, R., Vadrevu, K. M., Jogdand, H., Prasad, S., Reddy, S., Sarangi, V., Ganneru, B., Sapkal, G., Yadav, P., \& Abraham, P. (2021). Safety and immunogenicity of an inactivated SARS-CoV-2 vaccine, BBV152: a double-blind, randomised, phase 1 trial. The Lancet Infectious Diseases, 2021, 1-10.

Gao, Q., Bao, L., Mao, H., Wang, L., Xu, K., Yang, M., Li, Y., Zhu, L., Wang, N., \& Lv, Z. (2020). Development of an inactivated vaccine candidate for SARSCoV-2. Science, 369(6499), 77-81.

Gaspar, H. B., Parsley, K. L., Howe, S., King, D., Gilmour, K. C., Sinclair, J., Brouns, G., Schmidt, M., Von Kalle, C., \& Barington, T. (2004). Gene therapy of Xlinked severe combined immunodeficiency by use of a pseudotyped gammaretroviral vector. The Lancet, 364(9452), 2181-2187.

Graham, B. S. (1996). Immunological determinants of disease caused by respiratory syncytial virus. Trends in microbiology, 4(7), 290-294.

How COVID-19 spreads. (2020, October 28). Retrieved from https://www.cdc.gov/ coronavirus/2019-ncov/prevent-getting-sick/how-covid-spreads.html?

Humphreys, I. R., \& Sebastian, S. (2018). Novel viral vectors in infectious diseases. Immunology, 153(1), 1-9.

Jackson, L. A., Anderson, E. J., Rouphael, N. G., Roberts, P. C., Makhene, M., Coler, R. N., McCullough, M. P., Chappell, J. D., Denison, M. R., \& Stevens, L. J. (2020). An mRNA vaccine against SARS-CoV-2 - preliminary report. New England Journal of Medicine.

Jaume, M., Yip, M. S., Cheung, C. Y., Leung, H. L., Li, P. H., Kien, F., Dutry, I., Callendret, B., Escriou, N., \& Altmeyer, R. (2011). Anti-severe acute respiratory syndrome coronavirus spike antibodies trigger infection of human immune cells via a $\mathrm{pH}$-and cysteine protease-independent $\mathrm{Fc} \gamma \mathrm{R}$ pathway. Journal of virology, 85(20), 10582-10597.

Keech, C., Albert, G., Cho, I., Robertson, A., Reed, P., Neal, S., Plested, J. S., Zhu, M., Cloney-Clark, S., \& Zhou, H. (2020). Phase 1-2 trial of a SARS-CoV-2 recombinant spike protein nanoparticle vaccine. New England Journal of Medicine, 383(24), 2320-2332. 
Knezevic, I., Liu, M., Peden, K., Zhou, T., \& Kang, H. N. (2021). Development of mRNA vaccines: Scientific and regulatory issues. Vaccines, 9(2), 81. https://doi.org/10.3390/vaccines9020081

Mageit, S. (2021, March 8). Intranasal COVID-19 vaccines developed for additional protection. Mobi Health News. https://www.mobihealthnews.com/news/emea/ intranasal-covid-19-vaccines-developed-additional-protection

Moderna announces award from U.S. government agency BARDA for up to $\$ 483$ million to accelerate development of mRNA vaccine (mRNA-1273) against novel coronavirus. (2020, April 17). Retrieved from https://pipelinereview.com/ index.php/2020041774358/Vaccines/Moderna-Announces-Award-from-U.S.Government-Agency-BARDA-for-up-to-\$483-Million-to-AccelerateDevelopment-of-mRNA-Vaccine-mRNA-1273-Against-Novel-Coronavirus.html

Murdin, A. D., Barreto, L., \& Plotkin, S. (1996). Inactivated poliovirus vaccine: past and present experience. Vaccine, 14(8), 735-746.

National Library of Medicine (U.S.) (2020, October 23). Safety, Tolerability and Immunogenicity of a Coronavirus-Like Particle COVID-19 Vaccine in Adults Aged 18-55 Years. Identifier NCT04450004. https://clinicaltrials.gov/ct2/ show/study/NCT04450004

National Library of Medicine (U.S.) (2021, February 9). Study of a Recombinant Coronavirus-Like Particle COVID-19 Vaccine in Adults. Identifier NCT04636697. https://clinicaltrials.gov/ct2/show/NCT04636697

Novavax COVID-19 vaccine demonstrates $89.3 \%$ efficacy in UK phase 3 trial. (2021, January 28). Retrieved from https://ir.novavax.com/news-releases/news-releasedetails/novavax-covid-19-vaccine-demonstrates-893-efficacy-uk-phase-3\#: : text $=($ Nasdaq $\% 3 \mathrm{~A} \% 20 \mathrm{NVAX}) \% 2 \mathrm{C} \% 20 \mathrm{a}$, the $\% 20$ United $\% 20$ Kingdom $\% 20(\% 20$ $\mathrm{UK} \% 20)$.

Ou, X., Liu, Y., Lei, X., Li, P., Mi, D., Ren, L., Guo, L., Guo, R., Chen, T., \& Hu, J. (2020). Characterization of spike glycoprotein of SARS-CoV-2 on virus entry and its immune cross-reactivity with SARS-CoV. Nature communications, 11(1), 1-12. 
Pardi, N., Hogan, M. J., Pelc, R. S., Muramatsu, H., Andersen, H., DeMaso, C. R., Dowd, K. A., Sutherland, L. L., Scearce, R. M., \& Parks, R. (2017). Zika virus protection by a single low-dose nucleoside-modified mRNA vaccination. Nature, 543(7644), 248-251.

Plotkin, S. (2014). History of vaccination. Proceedings of the National Academy of Sciences, 111(34), 12283-12287.

Polack, F. P. (2007). Atypical measles and enhanced respiratory syncytial virus disease (ERD) made simple. Pediatric research, 62(1), 111-115.

Polack, F. P., Teng, M. N., L. Collins, P., Prince, G. A., Exner, M., Regele, H., Lirman, D. D., Rabold, R., Hoffman, S. J., \& Karp, C. L. (2002). A role for immune complexes in enhanced respiratory syncytial virus disease. The Journal of experimental medicine, 196(6), 859-865.

Polack, F. P., Thomas, S. J., Kitchin, N., Absalon, J., Gurtman, A., Lockhart, S., Perez, J. L., Pérez Marc, G., Moreira, E. D., \& Zerbini, C. (2020). Safety and efficacy of the BNT162b2 mRNA Covid-19 vaccine. New England Journal of Medicine, 383(27), 2603-2615.

Prompetchara, E., Ketloy, C., \& Palaga, T. (2020). Immune responses in COVID-19 and potential vaccines: Lessons learned from SARS and MERS epidemic. Asian Pac J Allergy Immunol, 38(1), 1-9.

Remy, K. E., Mazer, M., Striker, D. A., Ellebedy, A. H., Walton, A. H., Unsinger, J., Blood, T. M., Mudd, P. A., Yi, D. J., \& Mannion, D. A. (2020). Severe immunosuppression and not a cytokine storm characterizes COVID-19 infections. JCI insight, 5(17), e140329. https://doi.org/10.1172/jci.insight.140329

Sabchareon, A., Lang, J., Attanath, P., Sirivichayakul, C., Pengsaa, K., Le Mener, V., Chantavanich, P., Prarinyanuphab, V., Pojjaroen-Anant, C., \& Nimnual, S. (1999). A new vero cell rabies vaccine: results of a comparative trial with human diploid cell rabies vaccine in children. Clinical infectious diseases, 29(1), 141-149. https://doi.org/10.1086/520143 
Sahin, U., Muik, A., Vogler, I., Derhovanessian, E., Kranz, L. M., Vormehr, M., Quandt, J., Bidmon, N., Ulges, A., \& Baum, A. (2020). BNT162b2 induces SARS-CoV-2-neutralising antibodies and $\mathrm{T}$ cells in humans. medRxiv. https://doi.org/10.1101/2020.12.09.20245175

Serum Institute seeks emergency use authorisation for Oxford Covid-19 vaccine Covishield in India. (2020, December 7) Retrieved from https://health. economictimes.indiatimes.com/news/pharma/serum-institute-seeks-emergencyuse-authorisation-for-oxford-covid-19-vaccine-covishield-in-india/79600227

Shin, M. D., Shukla, S., Chung, Y. H., Beiss, V., Chan, S. K., Ortega-Rivera, O. A., Wirth, D. M., Chen, A., Sack, M., \& Pokorski, J. K. (2020). COVID-19 vaccine development and a potential nanomaterial path forward. Nature nanotechnology, 15(8), 646-655. https://doi.org/10.1038/s41565-020-0737-y

Tebas, P., Yang, S. P., Boyer, J. D., Reuschel, E.L., Patel, A., Christensen-Quick, A., ...., \& Humeau, L. M. (2021). Safety and immunogenicity of INO-4800 DNA vaccine against SARS-CoV-2: A preliminary report of an open-label, Phase 1 clinical trial. EClinicalMedicine, 31, 100689. https://doi.org/10.1016/j.eclinm.2020.100689

Ura, T., Okuda, K., \& Shimada, M. (2014). Developments in viral vector-based vaccines. Vaccines, 2(3), 624-641. https://dx.doi.org/10.3390\%2Fvaccines2030624

Vaccination update. (2021, March 20). Retrieved from https://github.com/owid/covid19-data/blob/master/public/data/vaccinations/country_data/India.csv

Vellozzi, C., Burwen, D. R., Dobardzic, A., Ball, R., Walton, K., \& Haber, P. (2009). Safety of trivalent inactivated influenza vaccines in adults: background for pandemic influenza vaccine safety monitoring. Vaccine, 27(15), 2114-2120. https://doi.org/10.1016/j.vaccine.2009.01.125

Voysey, M., Clemens, S. A. C., Madhi, S. A., Weckx, L. Y., Folegatti, P. M., Aley, P. K., Angus, B., Baillie, V. L., Barnabas, S. L., \& Bhorat, Q. E. (2021). Safety and efficacy of the ChAdOx1 nCoV-19 vaccine (AZD1222) against SARSCoV-2: an interim analysis of four randomised controlled trials in Brazil, South Africa, and the UK. The Lancet, 397(10269), 99-111. 
Wang, N., Shang, J., Jiang, S., \& Du, L. (2020). Subunit vaccines against emerging pathogenic human coronaviruses. Frontiers in microbiology, 11, 298.

WHO coronavirus disease (COVID-19) dashboard. (2021, March 22). Retrieved from https://covid19.who.int/

Williams, J. A. (2013). Vector design for improved DNA vaccine efficacy, safety and production. Vaccines, 1(3), 225-249.

World Health Organization (2021a, March 16). Draft landscape and tracker of COVID-19 candidate vaccines.. Retrieved from https://www.who.int/ publications/m/item/draft-landscape-of-covid-19-candidate-vaccines

World Health Organization, (2020b). mRNA vaccines against COVID-19: Pfizer-BioNTech COVID-19 vaccine BNT162b2: prepared by the Strategic Advisory Group of Experts (SAGE) on immunization working group on COVID-19 vaccines, 22 December 2020. Retrieved from https://apps.who.int/iris/handle/10665/338096

Wu, Z., Hu, Y., Xu, M., Chen, Z., Yang, W., Jiang, Z., Li, M., Jin, H., Cui, G., \& Chen, P. (2021). Safety, tolerability, and immunogenicity of an inactivated SARS-CoV-2 vaccine (CoronaVac) in healthy adults aged 60 years and older: a randomised, double-blind, placebo-controlled, phase 1/2 clinical trial. The Lancet Infectious Diseases. https://doi.org/10.1016/S1473-3099(20)30987-7

Zhang, Y., Zeng, G., Pan, H., Li, C., Hu, Y., Chu, K., Han, W., Chen, Z., Tang, R., \& Yin, W. (2021). Safety, tolerability, and immunogenicity of an inactivated SARS-CoV-2 vaccine in healthy adults aged 18-59 years: a randomised, double-blind, placebo-controlled, phase 1/2 clinical trial. The Lancet Infectious Diseases, 21(2), 181-192. https://doi.org/10.1016/S1473-3099(20)30843-4

How to cite this article: Syeda, S., \& Shrivastava, A. (2021). COVID-19 Vaccine: The Fight Against SARS-CoV-2 Infection. Vantage: Journal of Thematic Analysis, 2(1): 42-66. DOI: https://doi.org/10.52253/vjta.2021.v02i01.04

(C) The Author(s) 2021.

This work is licensed under a Creative Commons Attribution 4.0 International License which permits its use, distribution and reproduction in any medium, provided the original work is cited.

Vantage: Journal of Thematic Analysis, 2021; 2(1): 42-66 